\title{
Presentation of the Howland Award: Some Observations in Regard to Amos Christie, M. D.
}

\author{
ROBERT E. MERRILL
}

Department of Pediatrics, Southern Illinois University School of Medicine, Springfield, Illinois, USA

It is a singular honor for me to be selected to present these observations, and I wish to express my appreciation to all concerned.

The first figure (Fig. 1) is the best photograph of Dr. Amos Christie that I have been able to find. It was taken when he was in the midst of a trip around the world. The place is Greece at Delphi, the site of the oracle of Apollo. There remains some question in regard to who advised whom on this occasion. Nevertheless, note the warmth, and the genuine human qualities illustrated here. It is impossible to paint a word picture to better illustrate these attributes, although I will try.

This presentation consists of two parts. One is a brief biographical sketch. based on fact, and is reasonably accurate. The second is also based on fact, but is a personal interpretation of those facts, combined with other observations: in truth, a possibly fallible interpretation of a character that I have been privileged to know and admire for over a third of a century.

Dr. Christie's father's family emigrated from Ireland: members were identified in Boston before 1776, but as Loyalists (loyalty is a trait not new to the family) later surfaced in Nova Scotia and finally in California. His father, Fred, was highly regarded as a tough and expert lumberman in the redwood forests near Eureka, California. He died in 1906 and had virtually no direct influence on his infant son. Dr. Christie's mother, in her own way, must have been tougher. She did not remarry and raised her only child on what must have been a marginal income. She always found the means to provide for education and other important requirements. Her influence must have been considerable; what might now be termed a "good start in life" for Dr. Christie might have proved otherwise.

Local schooling in grade school, then high school, augmented by athletics and work, all culminated in a young man who was considered to be highly acceptable by a number of good universities. He worked in the lumber mill, as a paper boy, as an iceman and performed as a sprinter, hurdler, and blocking back, always successfully. Dr. Christie then enrolled at the University of Washington without benefit of a so-called grant-in-aid. However, it is alleged that he was aided considerably by the maternal admonitions: "never get in trouble" and "never disgrace me."

As a college student, reliability seemed to pervade his career. As a waiter on tables, a tackle noted for quickness, roommate of the star quarterback, a chemistry student, and the president of his fraternity, he repeatedly demonstrated that he could be counted upon, always. That he never got into trouble is possible, but unlikely. That he never disgraced his mother is true.

The Rose Bowl games (Fig. 2) (both losing efforts) of 1923 and 1924 are history-and the reliable tackle did play well on both occasions. He did have a literally sobering influence on his roommate, the quarterback. Had he not sobered him up, the game would have been out of reach. He did find himself being helped up by the gentlemen of the Naval Academy team after he had been knocked down by the same gentlemen, a custom unknown in the Pacific league. The next year he got an early taste of show business, playing against the legendary Alabama halfback, Johnny Mack Brown, who could, uniquely, play football and chew tobacco simultaneously without swallowing the latter. Brown may have been the better player, but Dr. Christie turned out to be the better actor. In those days, football players were allowed, but not en- couraged to take organic chemistry, a topic which could have interfered with the football.

After graduation, Dr. Christie was accepted by three medical schools and the athlete-turned-scientist chose the University of California. This choice was possibly related to tuition costs which his intrepid mother continued to find.

Flirting in medical school successfully with supra-vital staining as a histology assistant, and not so successfully with a wealthy grass widow, Dr. Christie then met the redoubtable Margaret Clarke. (Fig. 3)

When she and Dr. Christie met, she was the daughter of a physician and a young lady of considerable beauty and charm, not to mention talent as a singer and actress. This was Dr. Christie's second contact with show business and may well have been the origin of some of the "ham" in him that we have learned to enjoy. Margaret was acquainted with almost all of the greats of the stage at that time and had, indeed, been understudy to the renowned Jeannette McDonald. After a courtship of 6 months, the couple was married in 1934. The maternal admonitions had not been forgotten.

That she would exchange these exciting and glamorous friends for an ex-tackle interested in babies is probably a reflection of her intelligence. She subsequently served as an exemplary chairman's wife through countless staff parties, picnics, and other events, and has served as a splendid example to many. That many others would benefit from her influence is equally clear. Amid her academic duties, Mrs. Christie maintained a lively interest in the stage and the arts while raising their only daughter.

By the time the Christies were married, Dr. Christie had become an instructor in pediatrics at the University of California. He had graduated from medical school in 1929, and after a rotating internship, had served for a year at the Babies' Hospital in New York. By present standards, he was obviously not qualified for his faculty position. Even then, California was unique.

From that position, in rapid order, we find him as a research assistant in pediatrics at Hopkins (1936), assistant professor at the University of California (1937), associate professor (1939), acting head (1940), and Professor and Chairman at Vanderbilt University from 1943 until retirement in 1968. Some brief assignments are omitted, all of which aided the steady rise to a position of distinction.

It must be added that the career of this fascinating individual has not stopped with retirement, but seems to gain new dimensions with time. Membership on, or chairmanship of innumerable boards and commissions, an omniscient eye on each of the former residents, recurrent contributions to textbooks, recruiting for Vanderbilt University athletics, a trip around the world, and new topics for research and writing, including health care delivery have benefitted from his attention. The Student Health Coalition, advised by Dr. Christie is shown (Fig. 4). The organization is devoted to find ways to provide health care in underserved areas in Appalachia. With malice, the group has been called "Christie's Commies."

Concern for grandchildren, his own, and all of our children and grandchildren, and a legendary and absolute disdain for any and all evidence of physical frailty continue the list of the evidence of his failure, a failure to retire.

These are some of the characteristics which enhance Dr. Christie 


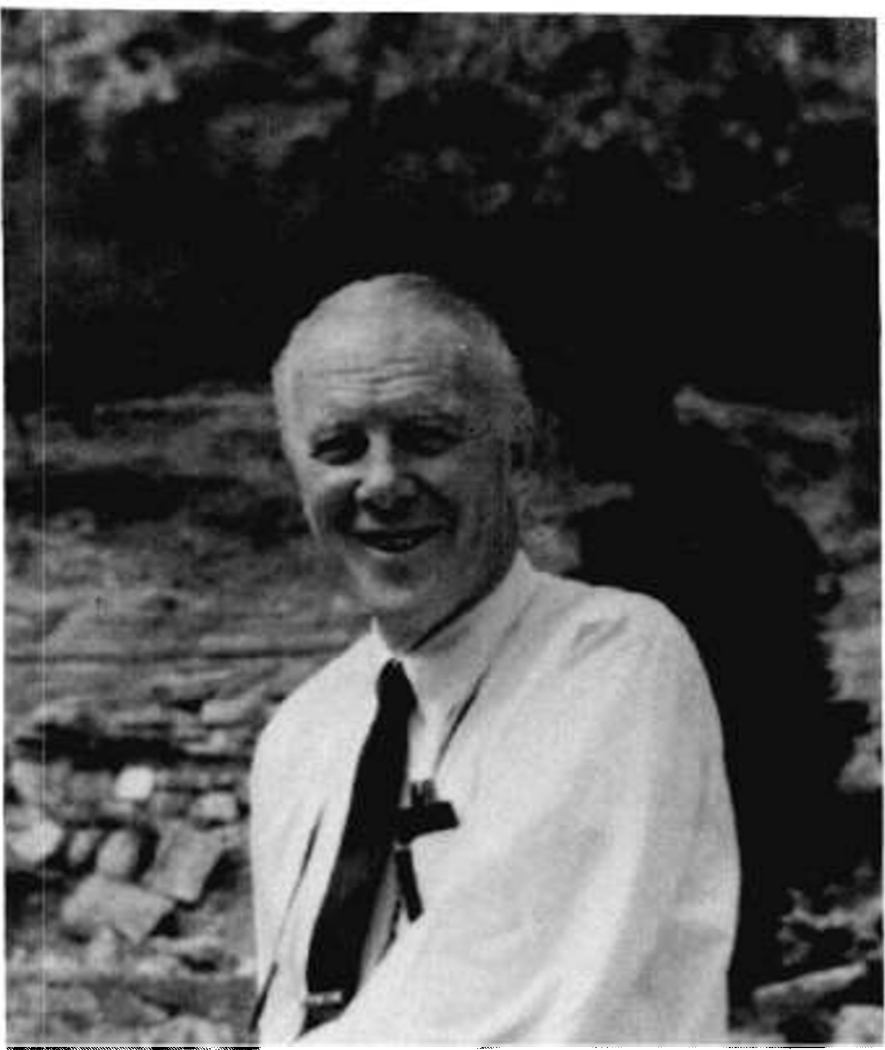

Fig. 1. Dr. Amos Christie

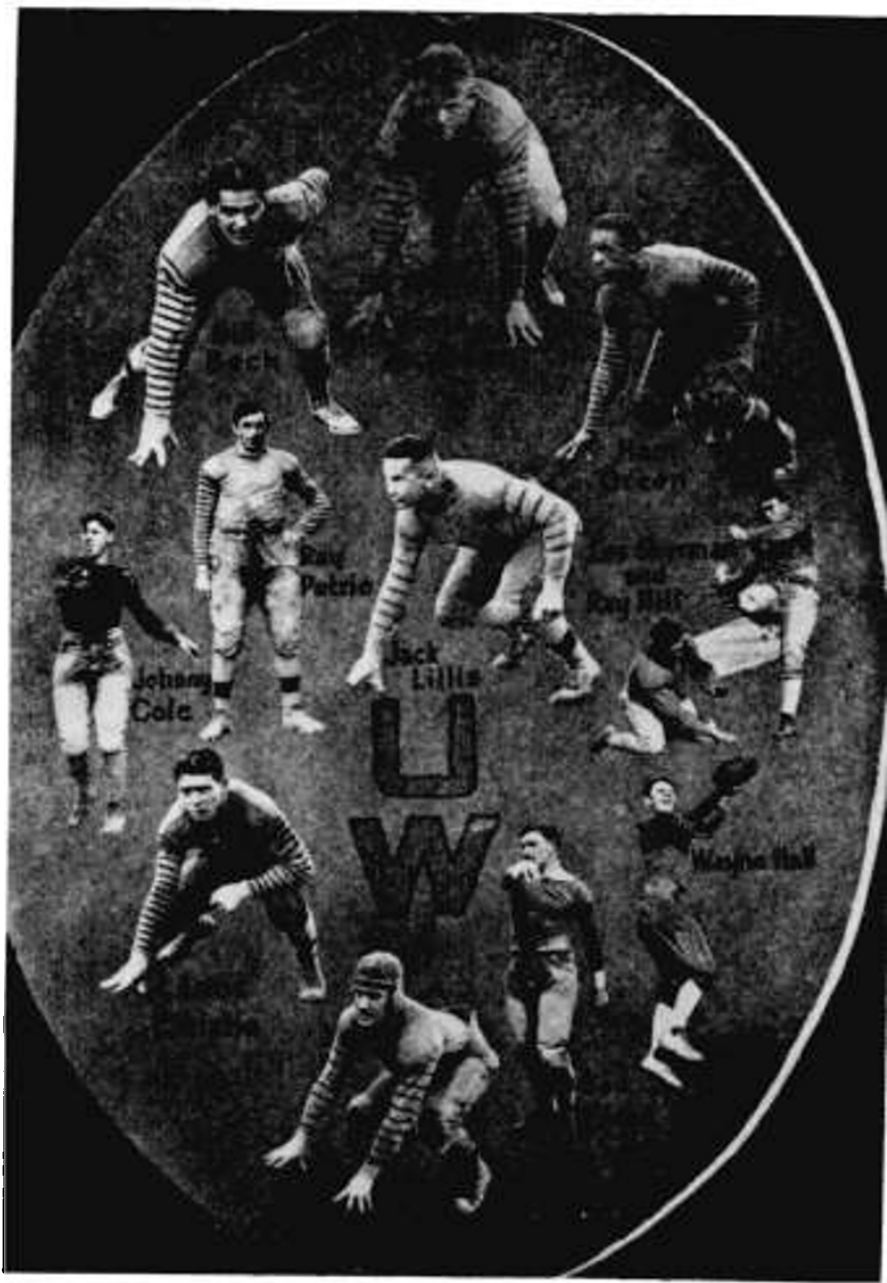

Fig. 2. Rose Bowl program-1923

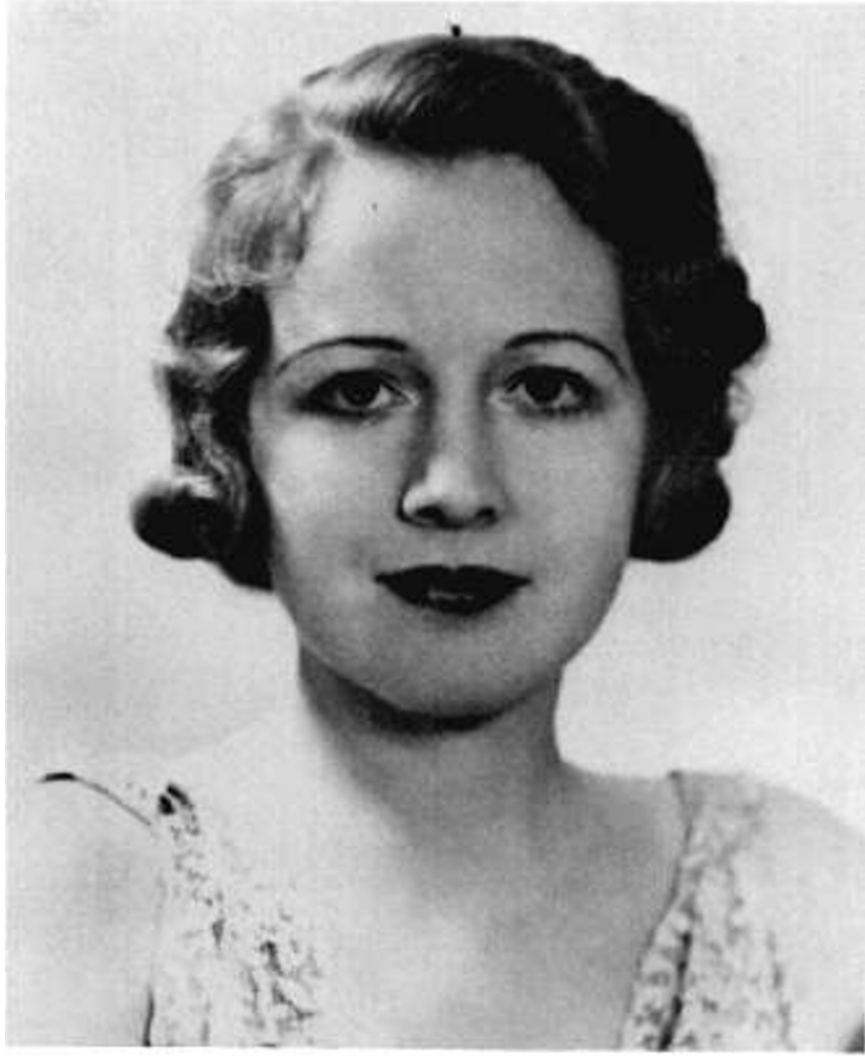

Fig. 3. Mrs. Amos Christie

in the eyes of us all. With them, and many other attributes, he has combined an uncanny ability to advance criticism, usually constructive and useful, sometimes painful, and frequently unsolicited. But all of this tends to avoid the primary issue: what is it that has permitted this former athlete to attain this kind of recognition?

Has it been teaching ability? I think not, although the talent is formidable. As a formal lecturer, the blanks were never consistently filled, sentences seldom concluded, participles dangled, and infinitives remained split. On the other hand, the ability to appear confused and dumb (like a fox) has led many unwary associates to expound with force and clarity on a topic. This is a device practiced by few: probably few of us have the self-assurance to chance it. Yet it took several experiences of this sort for some of us to decipher what was going on. I secretly suspect that a few have still not tumbled to it-after 30 years or more. To return to the question - is the key to preeminence in this man due to his teaching ability? A contributing factor, but in no way the key, in my estimation.

What about scientific inquiry? Some evidence of this talent will be presented here. It is notable that many of the observations made, have been rediscovered at $10-\mathrm{yr}$ intervals since. That the budgets attendant to these later publications have increased geometrically must be viewed sadly, as incidental intelligence.

The major work, that with histoplasmosis, will not be reviewed herein except to emphasize the completeness of it. Koch's postulates were not ignored. That the topic was wrapped up, nailed down, and put to bed was notable then and now. This emphasis might serve as a reminder to those who are tempted to gallop into print at the first glimpse of a new enzyme. The point is that the work was complete, conclusive, done with scientific integrity and vigor, extensive even by yesterday's standards: in short, formidable. However, it is not, in my opinion, the single most important facet of the man that requires this honor.

A third major endeavor of the academician is, of course, patient care, and in this area too, Dr. Christie has excelled. Measurements in this area are not readily available (PSRO notwithstanding), but countless parents and children, including many of the children of 


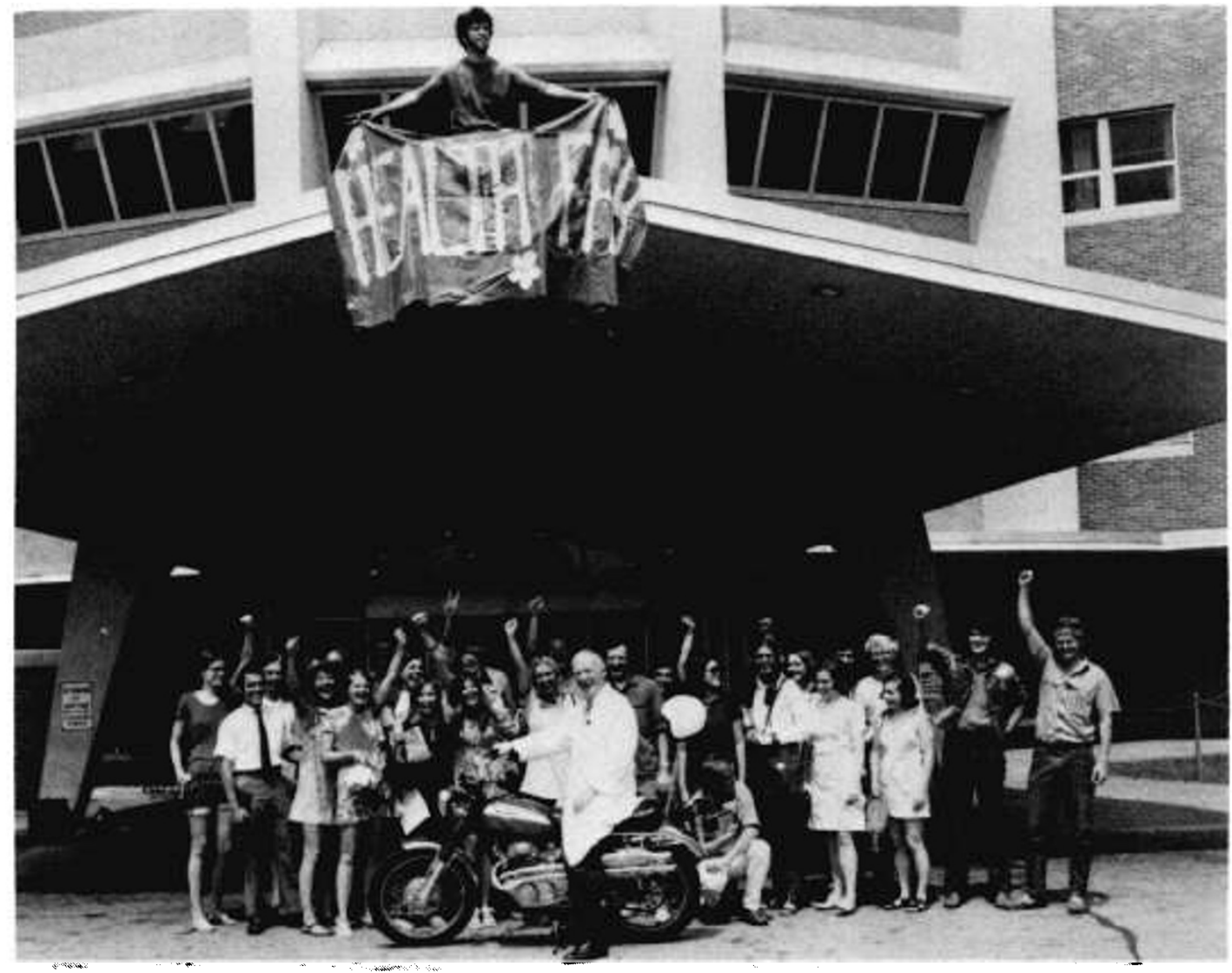

Fig. 4. Christie's Commies

those present, will attest to his wisdom, clinical instincts, and "presence"; in sum, the finest attributes of the physician, in contrast to the term doctor. The mixture, in practice of the science, with the art and, sometimes, true craft was, and remains a lesson for many of us. Again, a formidable talent, but not the essential ingredient.

I believe that the major contribution of this sometimes baffling man lay in his genius for administration. Not the administration as taught in text books or that practiced by personnel officers and bureaucrats. Rather, consider the word in the context of interpersonal relationships.

How he integrated the children's ward at Vanderbilt Hospital more than $15 \mathrm{yr}$ before it became fashionable and acceptable to do so is a story in itself. It was done in the interest of patient care. There was no committee, no permission granted, no authority vested, and no publicity. It was just done by executive decree. I call that administration.

He has caused all of us to rediscover the word "loyalty." That loyalty never flags, that loyalty returns in relationship to how far it is extended and that the resident is always right, until proof to the contrary is overwhelming, are but three little examples of a daily practice that pervaded everything we did. For those who have sustained, inter alia, a lump or two, this invariably generates more, not less, support from Dr. Christie.

That attitude of loyalty is basic-and to that must be added some illustrative quotations that shed insight into this genius for the management of all sorts and conditions of young physicians.

To all members of the staff: "If you're too busy to go fishing, you're too busy." This one drives personnel "experts" insane, as does the following.

To the new faculty member inquiring about how much vacation time he could have: "How much do you need?" This freedom was never abused.

To a very distinguished visitor: "This is Dr. Blank, my chief resident. I think he is really a frustrated English major." Even the mediocre resident attained a distinguishing mark.

When asked why we were retaining a certain individual on the resident staff: "I don't think he is ready for us to send out yet." How many chairmen will go this far?

And last, at a Vanderbilt basketball game: "I think if we get a 4-point lead, my extra systoles will stop." Loyalty again.

That a pediatric group in South Carolina would be named for him, that a portrait would be over-subscribed by the many recipients of this kind of guidance and that many in this room could add innumerable examples to this brief exposition is not surprising.

But it all culminates, in a mysterious way, in the true genius of Dr. Christie as I appraise it. That is his ability to allow, but not force, whatever talent may exist among the staff to develop in whatever direction it will and is most appropriate, a principle which is, after all, the essence of raising children. Add to that the ability to instill a desire for excellence, without compromise, and the result is the emergence of a number of people who probably have reached goals far beyond any reasonable predictions. We, the ordinary, know what the benefit of this influence has been. The rare exception, the truly talented and extraordinary were never really hindered, and I contend that the ability of this man to engender so much for so many from so little is miraculous. This is the true genius of the man, as I see it.

For all of us who have been associated with this great, talented, and almost always lovable teacher and friend, and for myself, I express our appreciation.

\section{REFERENCES AND NOTES}

1. This was read at the Annual Meeting of the American Pediatric Society, May, 1979, Atlanta, Georgia.

2. Dr. Merrill is Professor of Pediatrics, Southern Illinois University School of Medicine, P.O. Box 3926, Springfield, Illinois 62708, USA. 